\title{
Factors affecting genetic transformation by particle bombardment of the prickly pear cactus ( 0 . ficus-indica)
}

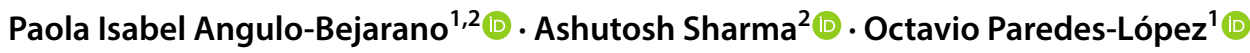

Received: 16 May 2018 / Accepted: 10 February 2019 / Published online: 20 February 2019

(c) The Author(s) 2019

\begin{abstract}
In the present study, a novel transformation protocol for Opuntia ficus-indica was generated by means of particle bombardment. The best conditions obtained were: 900 psi rupture disk pressure, $8 \mathrm{~cm}$ microprojectile travel distance, and $4 \mathrm{~h}$ of exposition to $0.2 \mathrm{M}$ mannitol. For all experiments, gold particles coated with $1.0 \mu \mathrm{g} / \mu \mathrm{L}$ of pBI426 plasmid DNA were used. With all these conditions, a 23\% of transformation efficiency in terms of regeneration in selection media (100 mg/L kanamycin) was obtained. Interestingly, the presence of both transgenes: nptII and uidA, by means of PCR and RT-PCR assays was detected. The regeneration percentage achieved in terms of stable integration for both genes was $10 \%$. In addition, we also detected adequate amounts of $\beta$-glucuronidase activity by means of the GUS fluorometric assay. The procedure described in the present investigation reveals the feasibility of using nopal for the introduction, expression, and possible production of heterologous proteins.
\end{abstract}

Keywords Cactus $\cdot$ Genetic transformation $\cdot$ Biolistics $\cdot$ Biotechnology

\begin{tabular}{|c|c|}
\hline \multicolumn{2}{|c|}{ Abbreviations } \\
\hline $2,4-\mathrm{D}$ & Dichlorophenoxyacetic acid \\
\hline BA & 6-bencilaminopurine \\
\hline CAM & Crassulacean acid metabolism \\
\hline CaMV35S & $\begin{array}{l}\text { Cauliflower mosaic virus } 35 \mathrm{~S} \text { constitutive } \\
\text { promoter }\end{array}$ \\
\hline GUS & $\beta$-glucuronidase enzyme \\
\hline nptII & $\begin{array}{l}\text { Gene coding for neomycin phosphotrans- } \\
\text { ferase II enzyme }\end{array}$ \\
\hline uidA & Gene coding for $\beta$-glucuronidase enzyme \\
\hline
\end{tabular}

\section{Introduction}

Nopal (O. ficus-indica) belongs to the Cactaceae family, subfamily Opuntioideae, and constitutes the cactus species with the highest economic importance worldwide. It is grown

Octavio Paredes-López

octavio.paredes@cinvestav.mx

1 Centro de Investigación y de Estudios Avanzados-IPN, Unidad Irapuato, Km 9.6 Libr. Norte Carr. Irapuato-León, Apdo. Postal 629, Irapuato, 36824 Guanajuato, Mexico

2 Tecnologico de Monterrey, School of Engineering and Sciences, Epigmenio González No. 500 Fracc. San Pablo, 76130 Queretaro, Queretaro, Mexico in America, Africa, Asia, Europe, and Oceania (AnguloBejarano and Paredes-López 2012). The number of species belonging to the Opuntia genus may range between 160 (Gibson and Nobel 1986) and 250 (Britton and Rose 1963) and most of them are thought were originated in Mexico. At present, it is considered important for its use as food and forage, and as a source for nutraceuticals (Angulo-Bejarano et al. 2014).

Nopal plants are able to thrive under extremely contrasting environmental conditions, such as poor soils with low pH (Blanco et al. 2003). In addition, they are highly efficient in terms of water usage, mainly due to their CAM metabolism (Herrera 2009). Nopal plants are also characterized for a slow growth due to a long juvenile phase in comparison with asexually propagated material (Silos-Espino et al. 2006). The main meristematic tissue arises from structures called areoles which cover the stems, and that can be stimulated or activated during most in vitro tissue protocols in nopal (Angulo-Bejarano and Paredes-López 2011).

The introduction of new traits in the prickly pear cactus relies on the establishment of gene transfer technologies. In fact, the use of such technologies may aid for increasing nutritional value or in the production of nutraceuticals. A reliable plant genetic transformation system is imperative to allow the use of nopal as a plant bioreactor for the production of commercial or therapeutic molecules. In fact, nopal 
is a potential candidate to be used as plant bioreactor system due to its capacity to thrive in contrasting environmental conditions and to its high water usage efficiency, among other possibilities (Angulo-Bejarano 2013).

The feasibility for heterologous DNA integration in nopal was formerly described by our research group in 2006, where explants from $O$. ficus-indica cv. "Villanueva" were utilized and stably transformed by means of Agrobacterium tumefaciens (Silos-Espino et al. 2006). This report demonstrates, apparently for the first time, the use of prickly pear cactus in the expression of recombinant proteins. However, several attempts had been made previously to achieve genetic transformation through particle bombardment in $O$. ficus-indica. In 1998, Llamoca-Zarate et al. reported particle bombardment on friable calli of nopal cell suspensions. The transient expression of uidA and nptII genes was described, but no stable integration of these genes was registered. In a second attempt, they reported the transient expression of the uidA gene in shoot apical meristems from nopal without evidence for stable foreign DNA integration (Llamoca-Zarate et al. 1999a, b). Another study depicted particle bombardment in nopal shoot apical meristems that were transiently transformed to express the uidA and Atahas gene. Nevertheless, no stable integration of the transgene was described (Cruz et al. 2009). Therefore, the aim of the present study was to establish the most suitable conditions for particle bombardment in nopal by means of transient GUS expression and to assess the stable integration of foreign DNA by the molecular analyses.

\section{Materials and methods}

\section{Materials}

For all experiments $O$. ficus-indica cv. "Blanco sin Espinas", a commercial variety that was kindly provided by PRONOPVAL at Valtierrilla, Guanajuato was used. The cladodes were disinfested and micropropagated according to GarcíaSaucedo et al. (2005). In addition, to validate the transformation process, leaf explants from micropropagated Nicotiana tabacum var. Xanthi were used as a control. Tobacco internode micropropagation was done according to the method reported by Camacho-Beltrán (2008).

For the genetic transformation process, we utilized the pBI426 plasmid which was first described in Datla et al. (1991) (Fig. 1). The plasmid DNA was isolated using the PureLink ${ }^{\mathrm{TM}}$ Quick Plasmid Miniprep Kit from Invitrogen, following the manufacturer's protocol. The plasmid DNA obtained was quantified in a Nanodrop ${ }^{\circledR}$ NE-1000 equipment and analyzed in $0.8 \%$ agarose gel stained with ethidium bromide.

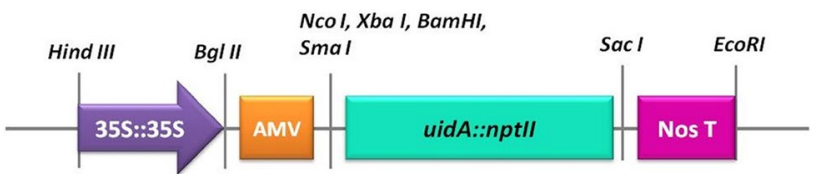

Fig. 1 Schematic representation of a fragment of pBI426 plasmid used for nopal genetic transformation, adapted from Datla et al. (1991). Double CaMV 35S promoter; a leader sequence from alfalfa mosaic virus (AMV), a transcriptional fusion between uidA and $n t p I I$ genes, and the nos terminator

\section{Preparation of microcarriers}

\section{Tungsten particles}

Sixty milligrams of tungsten particles (M-10) were re-suspended in $1.5 \mathrm{~mL}$ of $0.1 \mathrm{~N} \mathrm{HNO}_{3}$ and processed according to the protocol described by Camacho-Beltran (2008).

\section{Gold particles}

Sixty milligrams of gold particles $\left(0.6 \mu \mathrm{m}\right.$, Biorad ${ }^{\circledR}$ Hercules, CA. USA) were prepared according to Daniell et al. (2005).

\section{Establishment of the ideal conditions for particle bombardment in nopal explants, by transient GUS expression}

Nopal micropropagated plantlets were cut in approximately $1 \mathrm{~cm}^{2}$ explants and placed carefully in the center of a Petri plate $(60 \times 15 \mathrm{~mm})$ avoiding the presence of empty spaces between them due to the irregular morphology of explants. Four explants were used per bombardment event. Each Petri plate contained the osmotic medium which, for the first experiments (testing helium rupture disk pressure, distance of flight, time of exposure, DNA concentration, and type of particle) contained MS (Murashige and Skoog 1962) basal salts supplemented with maltose $15 \% \mathrm{v} / \mathrm{v}$ adjusted to $\mathrm{pH} 5.7$ and solidified with $7 \mathrm{~g} / \mathrm{L}$ agar.

The effect of rupture disk pressure and microprojectile distance was determined by analyzing three different rupture disk pressures: 450,900 , and 1350 psi, versus three distances $(8,11$, and $14 \mathrm{~cm})$ of flight allowed by the particle bombardment gun. The time of exposure to the osmotic agent previous to particle bombardment was adjusted; thus, the effect of 4,6 , and $8 \mathrm{~h}$ was examined. In addition, we evaluated the effect of DNA concentration loaded into the microcarriers; therefore, the use of $0.5,1$, and $1.5 \mu \mathrm{g} / \mu \mathrm{L}$ was tested. In addition, we evaluated the effect of using either tungsten or gold particles. Finally, the effect of different osmotic agents 
(maltose, mannitol, sorbitol, and their combinations, all at a concentration of $0.2 \mathrm{M}$ ) was assessed. In all cases, tobacco leaf explants were used as positive control.

After each biolistic event, the explants were kept under dark conditions at $28 \pm 2{ }^{\circ} \mathrm{C}$ to allow for their recovery. Then, they were analyzed for transient GUS expression by the histochemical staining method reported by Jefferson et al. (1987). Blue spots or stains (foci) were considered as positive uidA gene integration events and were considered as an expression unit, which was registered numerically (Hagio et al. 1995).

\section{Statistical analysis}

Data were analyzed using one-way analysis of variance (ANOVA). The means were compared with Tukey's Honestly Significant Difference (HSD) at $\alpha=0.05$. Only in the case of the type of osmotic medium, we used Duncan's test at $\alpha=0.05$. For all analyses, the software Statgrafics CENTURION XV (Statistical Graphics, Co) was used.

\section{Stable nopal transformation by particle bombardment}

After bombardment, the explants were allowed to recover under dark conditions as described previously. Next, they were transferred to the indirect organogenesis regeneration medium (Angulo-Bejarano and Paredes-López 2011). MS supplemented with $0.5 \mathrm{~g} / \mathrm{L} 2,4-\mathrm{D}$ and $0.5 \mathrm{~g} / \mathrm{L} \mathrm{BA}$, pH 5.7 solidified in $7 \mathrm{~g} / \mathrm{L}$ agar without a selecting agent during the first 15 days. After this period, they were transferred to MS medium supplemented with $50 \mathrm{mg} / \mathrm{L}$ kanamycin (15 days) and $100 \mathrm{mg} / \mathrm{L}$ (30 days) where they were kept until the end of the experiment. In all cases, a photoperiod of $16 \mathrm{~h}$ light $/ 8 \mathrm{~h}$ darkness and $28 \pm 2{ }^{\circ} \mathrm{C}$ was used. Transformation efficiency in terms of the survival in the selection medium was established as the number of green, healthy and sprouting explants in selection medium related to the total number of bombarded explants.

\section{Molecular analysis}

Total genomic DNA was isolated from resistant explants of putatively transformed plants according to Angulo-Bejarano (2013) and used to detect the presence of the uidA and nptII transgenes by polymerase chain reaction (PCR). To amplify a $617 \mathrm{bp}$ fragment of the nptII gene, we utilized the following set of primers: $\boldsymbol{n p t I I}$ forward 5'-TATTCGGCTATGACT TGGGC-3' and nptII reverse 5'-GCCAACGCTATGTCC TGATA-3'. In addition, to amplify a 534 bp fragment of the uidA gene, the following set of primers: uidA forward 5' - CGTCCTGTAGAAACCCCAAC-3' and uidA reverse 5'CGGCGTGGTGTAGAGCATTA-3' were used.
Total RNA was extracted according to the method of Valderrama-Chairez et al. (2002). Approximately $0.5 \mathrm{~g}$ of fineground nopal tissue previously frozen in liquid nitrogen was used for the extraction procedure. The total RNA extracted was used for RT-PCR analysis. A range of 1-3 $\mu \mathrm{g}$ of total RNA from all samples was used for c-DNA synthesis. To validate the quality of the c-DNA obtained, a $500 \mathrm{bp}$ fragment of the actin gene was amplified (data not shown). The c-DNA obtained was used as template to amplify the same fragments for $n p t I I$ and uidA genes.

$\beta$-glucuronidase expression, utilizing the fluorometric assay described by Jefferson et al. (1987), was also analyzed. Approximately 100-200 mg of fine-ground tissue previously frozen in liquid nitrogen, from putatively transformed and untransformed plants, was used for this assay. Protein quantification was done utilizing the $\mathrm{BCA}^{\mathrm{TM}}$ Protein Assay Kit (Pierce, Rockford, IL, USA). 4-10 $\mu$ g of protein extract were mixed with the GUS Assay Buffer; all readings were done with a fluorometer (Hoefer DyNA Quant 200; Pharmacia Biotech, Golden Valley, MN, USA). A commercial $\beta$-glucuronidase (Sigma-Aldrich, St. Louis MO, USA) was used as standard for all the readings.

Transformation efficiency in terms of the molecular analyses was expressed as the number of explants that were PCR, RT-PCR, and GUS fluorescent positive versus the overall bombarded explants.

\section{Results}

\section{Particle bombardment conditions for Opuntia explants}

The best particle bombardment conditions were established by means of analyzing the transient GUS expression in $1 \mathrm{~cm}^{2}$ micropropagated nopal explants. As a first condition, we evaluated the effect of helium pressure (450, 900, and 1350 psi) versus the distance of flight $(8,11$ and $14 \mathrm{~cm})$ (Table 1). We found statistical differences among the helium pressures analyzed ( $\alpha=0.05) 900$ psi being the most adequate, with the highest foci formation levels. No statistical differences were found between the use of 450 and 1350 psi. On the other hand, significant statistical differences $(\alpha=0.05)$ were found among the distances of flight analyzed; $8 \mathrm{~cm}$ was the most appropriate, since it allowed for the highest foci formation in nopal explants (Table 1; Fig. 2a).

The effect of the exposition time to an osmotic agent, previous to particle bombardment, was also analyzed. For these first adjustments, we utilized maltose $15 \%$ (v/v). According to Tukey's HSD test, statistical differences $(\alpha=0.05)$ were found between the use of $4 \mathrm{~h}$ and the rest of the exposition times analyzed (Table 1; Fig. 1b). Similarly, we evaluated the effect of plasmid DNA concentration loaded in

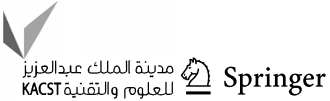


Table 1 Establishment of conditions for particle bombardment in $O$. ficus-indica explants through transient expression

\begin{tabular}{|c|c|c|}
\hline Pressure (Psi) & Distance $(\mathrm{cm})$ & $\begin{array}{l}\text { Foci number } \\
(\text { mean } \pm \text { SEM })^{*}\end{array}$ \\
\hline \multicolumn{3}{|l|}{ Pressure and distance of flight } \\
\hline \multirow[t]{3}{*}{450} & 8 & $0.66 \pm 0.14^{\mathrm{b}}$ \\
\hline & 11 & $0^{\mathrm{b}}$ \\
\hline & 14 & $0^{\mathrm{b}}$ \\
\hline \multirow[t]{3}{*}{900} & 8 & $18.83 \pm 4^{\mathrm{a}}$ \\
\hline & 11 & $0.47 \pm 0.13^{\mathrm{b}}$ \\
\hline & 14 & $0^{\mathrm{b}}$ \\
\hline \multirow[t]{3}{*}{1350} & 8 & $4.28 \pm 0.76^{\mathrm{b}}$ \\
\hline & 11 & $0.96 \pm 0.21^{b}$ \\
\hline & 14 & $0.97 \pm 0.28^{b}$ \\
\hline \multicolumn{3}{|l|}{ Exposition time (h) } \\
\hline \multicolumn{2}{|l|}{4} & $38 \pm 0.44^{\mathrm{a}}$ \\
\hline \multicolumn{2}{|l|}{6} & $8.5 \pm 0.08^{\mathrm{b}}$ \\
\hline \multicolumn{2}{|l|}{8} & $7 \pm 0.26^{\mathrm{b}}$ \\
\hline \multicolumn{3}{|l|}{ DNA concentration $(\mu \mathrm{g} / \mu \mathrm{L})$} \\
\hline \multicolumn{2}{|l|}{0.5} & $7.46 \pm 1.02^{\mathrm{b}}$ \\
\hline \multicolumn{2}{|l|}{1.0} & $23.93 \pm 3.55^{\mathrm{a}}$ \\
\hline \multicolumn{2}{|l|}{1.5} & $14.46 \pm 1.8^{\mathrm{ab}}$ \\
\hline \multicolumn{3}{|l|}{ Particle type } \\
\hline \multicolumn{2}{|l|}{ Gold } & $53.14 \pm 0.29^{\mathrm{a}}$ \\
\hline \multicolumn{2}{|l|}{ Tungsten } & $29.16 \pm 0.21^{\mathrm{b}}$ \\
\hline \multicolumn{3}{|l|}{ Osmotic medium $(0.2 \mathrm{M})^{* *}$} \\
\hline \multicolumn{2}{|l|}{ Mannitol } & $197 \pm 6.7^{\mathrm{a}}$ \\
\hline \multicolumn{2}{|l|}{ Sorbitol } & $137 \pm 4.5^{\mathrm{b}}$ \\
\hline \multicolumn{2}{|l|}{ Maltose } & $0^{\mathrm{c}}$ \\
\hline \multicolumn{2}{|l|}{ Maltose/sorbitol } & $25 \pm 3.2^{\mathrm{c}}$ \\
\hline \multicolumn{2}{|l|}{ Mannitol/maltose } & $21 \pm 1.63^{\mathrm{c}}$ \\
\hline \multicolumn{2}{|l|}{ Mannitol/sorbitol } & $0 \pm 0.125^{\mathrm{c}}$ \\
\hline \multicolumn{2}{|l|}{ Mannitol/sorbitol/maltose } & $2.3 \pm 0.0^{\mathrm{c}}$ \\
\hline
\end{tabular}

*Means with same letter are not significantly different according to Tukey's Honestly Significant Difference (HSD) at $\alpha=0.05$

**Means with the same letter are not significantly different according to Duncan's test at $\alpha=0.05$

tungsten particles. According to our findings, we observed a statistically significant difference $(\alpha=0.05)$ between the use of $1 \mu \mathrm{g} / \mu \mathrm{L}$ and the rest of the evaluated concentrations (Table 1; Fig. 2c). Next, we analyzed the effect of particle type (tungsten and gold particles). Remarkable differences were found between the use of tungsten versus gold particles in nopal. Gold particles were more effective in terms of overall foci production, leading to a statistically significant difference $(\alpha=0.05)$ between these treatments. Therefore, thereafter, all the remaining analyses were done with gold particles (Table 1; Fig. 2d). Finally, we evaluated different osmotic agents. Seven different media were analyzed at a constant concentration of $0.2 \mathrm{M}$. We found statistically significant differences among all the analyzed treatments
( $\alpha=0.05$ ) according to the Duncan test. The best treatment in terms of foci formation was mannitol at $0.2 \mathrm{M}$. Remarkable differences were found with mannitol $0.2 \mathrm{M}$ compared to the rest of the treatments. However, sorbitol also gave acceptable foci levels (Table 1; Fig. 2e). Surprisingly, we did not find a synergic effect between all the combinations of osmotic agents analyzed that could enhance the uidA transient expression. This was particularly interesting for the mannitol + sorbitol treatment, since they did generate high foci formation levels per explants, on their own, but, when we combined them, we did not observe a positive effect. No positive GUS expression was observed in nopal untransformed explants (Fig. 2f), confirming that this plant does not possess endogenous GUS production.

\section{Transient expression}

With the conditions generated by transient expression, we evaluated stable gene integration in nopal explants. To determine the effect of our conditions on nopal cell damage and recovery after the biolistics process and to discard a low regeneration frequency due to mechanical damage, we made some shootings with unloaded gold particles (negative controls) in $1 \mathrm{~cm}^{2}$ nopal explants and also in $N$. tabacum var. Xanthi leaf sections. No statistical differences were found among the bombarded explants with respect to untreated nopal explants growing on regeneration medium (Fig. 3a). Thereby, we proceeded to our first stable transformation assay; 300 explants were bombarded, which were transferred to regeneration/selection medium (Fig. 3b, c). These explants were kept in this medium for 45 days, doing periodic transfers to fresh selection medium every 15 days to avoid antibiotic degradation which leads to false positives. During this time, we observed that non-transformed explants showed a high oxidation level and no regeneration. Overall transformation efficiency in terms of new bud formation and healthy appearance resulted in a $23 \%$ level of regeneration efficiency. Transient GUS expression was evident after particle bombardment events (Fig. 3d).

\section{Stable integration of genes in nopal explants}

Nopal explants were transformed by the biolistic process as analyzed by means of PCR. A $617 \mathrm{bp}$ fragment of the $n p t I I$ gene located between the 1606 and $2221 \mathrm{pb}$ of the pBI426 plasmid was detected in seven out of ten samples analyzed (Fig. 4a). Moreover, a 534 bp fragment of the uidA gene was also detected among the entire samples (Fig. 4b). To effectively demonstrate the expression of both transgenes in the transformed nopal explants, we proceeded to the RT-PCR analysis. Total RNA was isolated from ten samples of putative transformed nopal explants, untransformed nopal explants (negative control), and transformed N. tabacum var Xanthi 

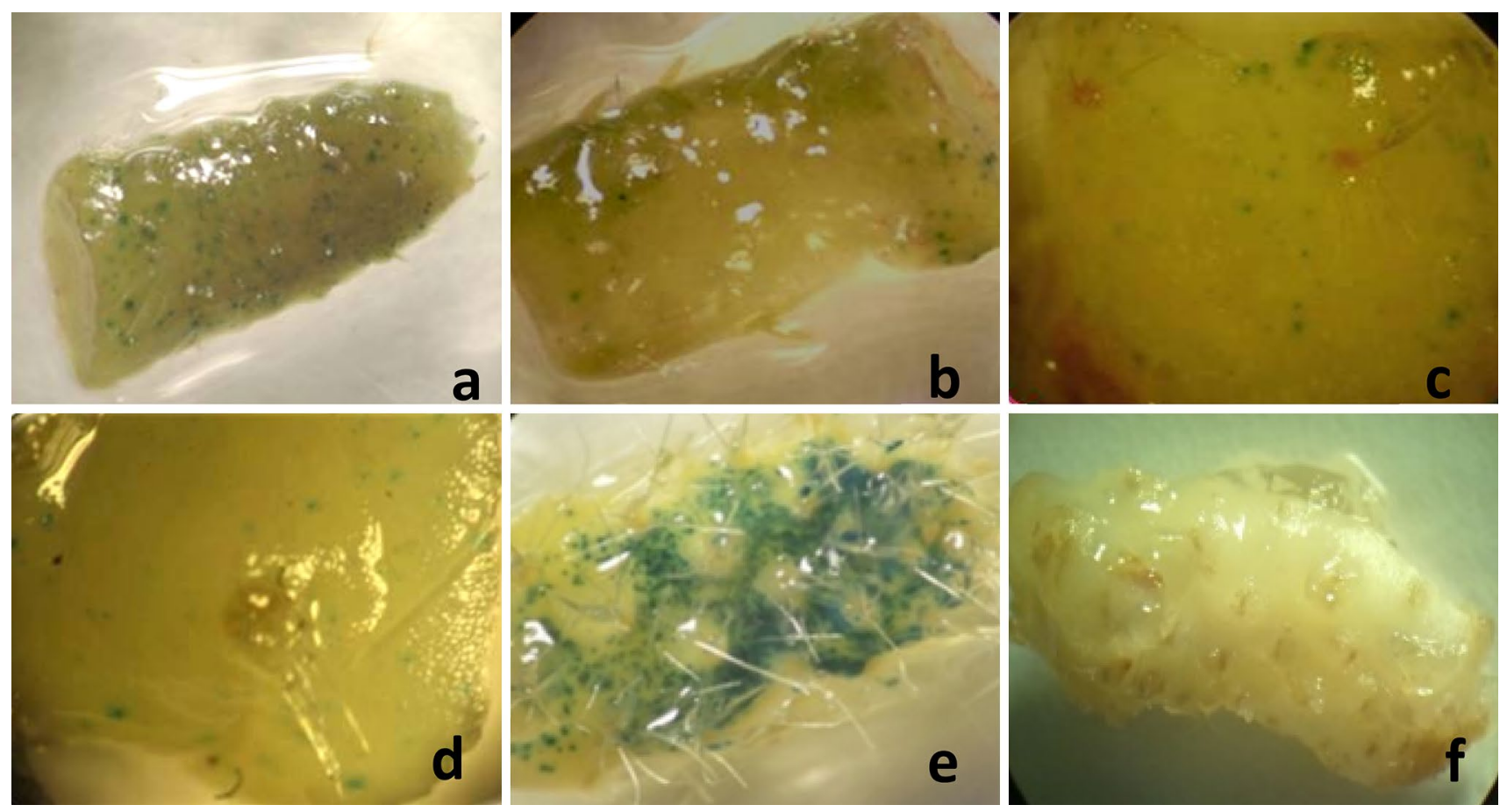

Fig. 2 Results of the adjustment of particle bombardment conditions for nopal explants by means of transient uidA expression. a 900 psi and $8 \mathrm{~cm}$ distance of flight, $\mathbf{b}$ time of exposition to the osmotic agent
(4 h), c plasmid DNA concentration $(1 \mu \mathrm{g} / \mu \mathrm{L})$, d type of microcarrier (gold); e type of osmotic agent (mannitol 0.2 M), f untransformed nopal used as negative control for endogenous GUS expression leaf sections (Fig. 5a). These RNA samples were utilized to synthesize complementary DNA and to validate its quality; we amplified a $500 \mathrm{bp}$ fragment for the actin gene in all samples (Fig. 5b). We were capable of detecting the presence of the nptII gene in the ten samples (Fig. 5c). Interestingly, the presence of the uidA gene was detected in only eight out of ten samples (Fig. 5d). To analyze the expression of the $\beta$-glucuronidase protein in transformed nopal explants, we conducted a GUS fluorescent assay in ten nopal transformed explants as well as samples of untransformed nopal explants (negative control).

The GUS values reported here are the results of four repetitions in all samples. In general, GUS values were in average $304 \mathrm{MU} / \mathrm{min} / \mathrm{mg}$ of protein for the transformed explants, which were really low when compared to our positive control ( $\beta$-glucuronidase) which exhibited $24474 \mathrm{MU} / \mathrm{min} / \mathrm{mg}$ of protein. No significant statistical differences $(\alpha=0.05)$ were observed among the activities found in the transformed explants, but a significant difference was observed in relation with the positive control and negative control (no expression was observed in these samples).

\section{Discussion}

\section{Ideal conditions for particle bombardment in nopal}

The genetic transformation of nopal is a very difficult process, as has been reported previously (Llamoca-Zarate et al. 1998, 1999a, b, Silos-Espino et al. 2006; AnguloBejarano 2013). In particular, genetic transformation by particle bombardment is marked by low efficiency of stably transformed cells, and thus, condition optimization is necessary. In addition, several conditions affect stable transformation in biolistics, namely: mechanical damage, toxicity, and the adjustment of pressure, distance of flight, and type of particles. A balance between minor damage caused by particle bombardment and a high number of cells transiently expressing the transgene is desirable 

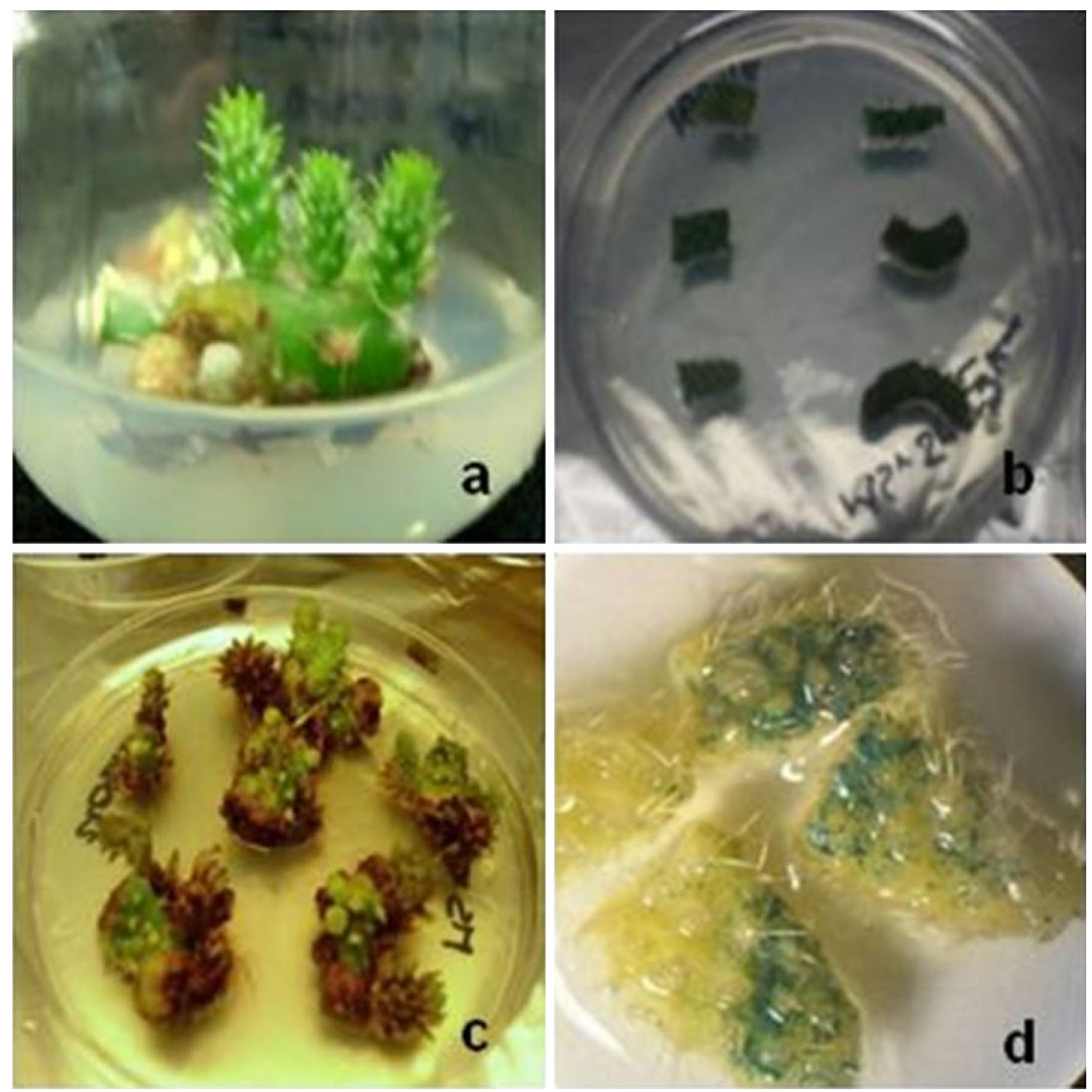

Fig. 3 Nopal biolistic transformation. a Negative controls after particle bombardment with unloaded gold particles, b nopal explants after particle bombardment, (c) nopal transformed explants after 45 days in selection medium (100 mg/L kanamycin), d uidA transient expression in transformed nopal explants
Fig. 4 PCR amplification of the $n p t I I$ and uidA transgenes in transformed nopal explants. a $534 \mathrm{bp}$ fragment of the uidA gene, $\mathbf{b} 617 \mathrm{bp}$ fragment of the nptII gene. (+), pBI426 (positive control), and transformed nopal samples (lanes 1 to 10), Ofint, untransformed nopal samples, tab, transformed $N$. tabacum, (-) deionized sterile water. $1 \mathrm{~kb}$ molecular weight marker
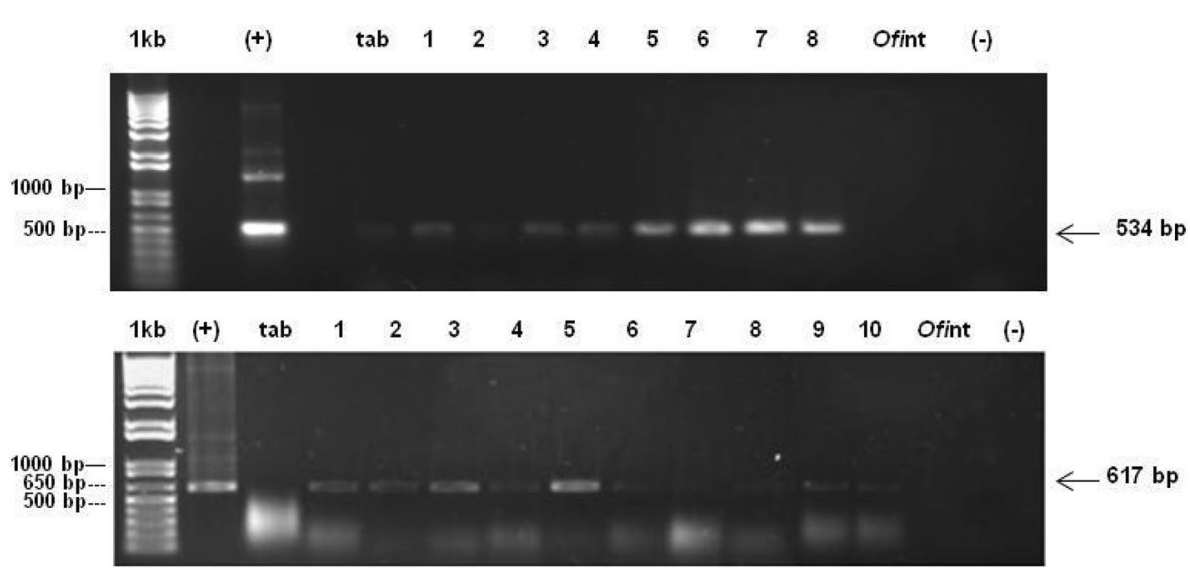
Fig. 5 RT-PCR detection of both (nptII and uidA) genes in transformed nopal explants. a Total RNA, tab: N. tabacum, transformed nopal samples (lanes 1-10), and nt: untransformed nopal, b c-DNA from different samples, (+) actin gene tab: N. tabacum c-DNA, c-DNA from transformed nopal samples (lanes 1-10), nt untransformed nopal, c-DNA, c 617 bp fragment amplification of the nptII gene, (+) pBI426 plasmid DNA (positive control), tab: tobacco c-DNA, transformed nopal samples (lanes 1-10), Ofint: untransformed nopal sample, $\mathbf{d}$ 534 bp fragment amplification of the uidA gene, (+) pBI426 plasmid DNA, transformed nopal samples (lanes 1-8), Ofint: untransformed nopal sample. $1 \mathrm{~kb}$ : molecular weight marker. (-) deionized sterile water
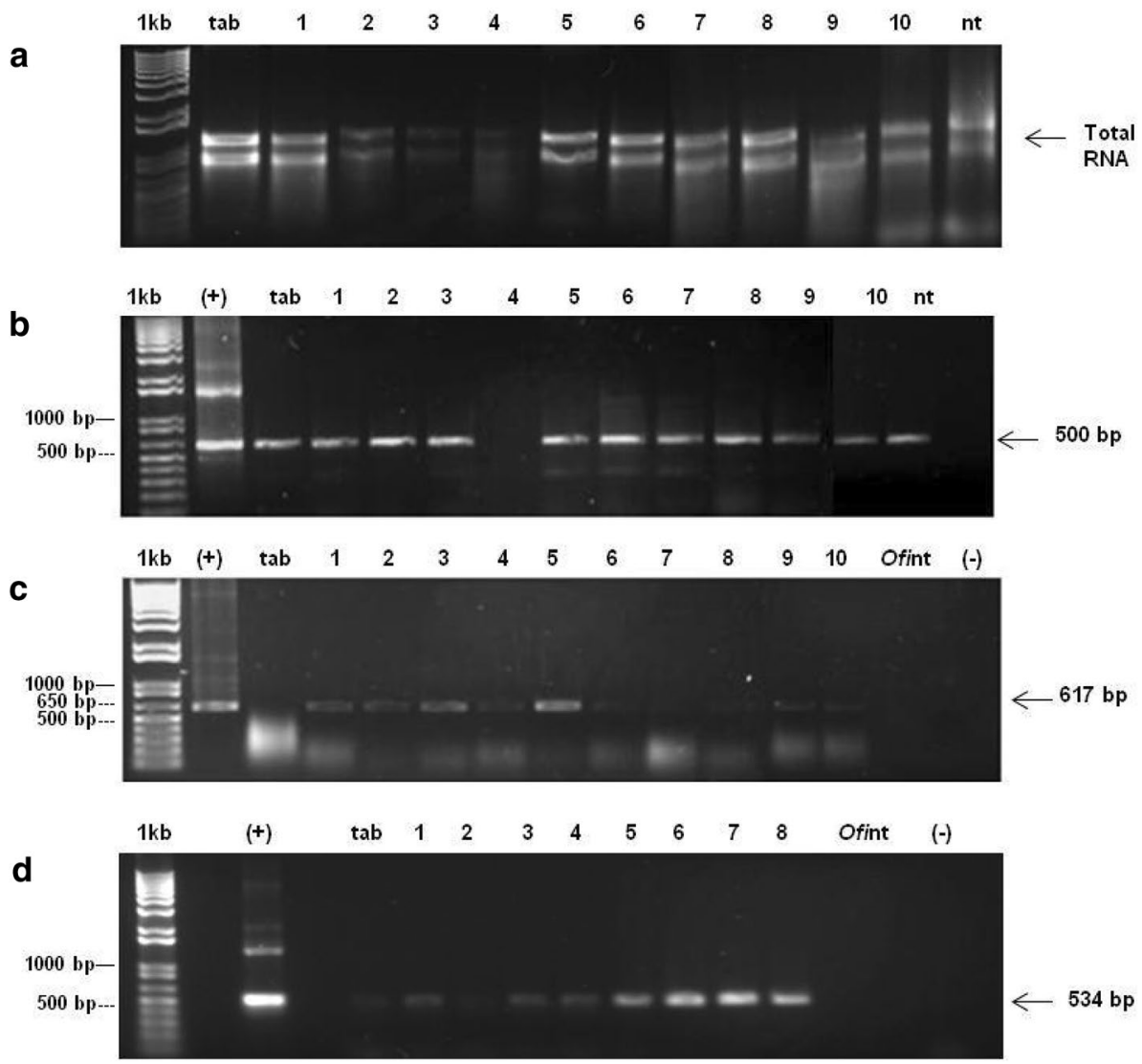

(Chernobrovkina et al. 2007). Our results are not a product of optimization, but rather arise from the search for best particle bombardment conditions for nopal that pursuit high foci formation levels to ensure in part, a much higher number of stably transformed cells.

The previous reports have indicated the influence of helium pressure and target tissue distance on DNA entrance and tissue damage in plant cells (Rubio et al. 2004). In nopal, high-pressure systems using 1200 psi and $7.5 \mathrm{~cm}$ in callus and apical cultures led to satisfactory transient expression (Llamoca-Zarate et al. 1998, 1999b). However, higher transient expression levels were found in our investigation when applying a lower helium pressure (Table 1; Fig. 2a, b). In fact, at lower pressure, less tissue damage is inflicted (Petrillo et al. 2008). In addition, distance of flight has a very important role in tissue damage and DNA penetration in plants. In our study, when we increased the distance of flight, the GUS transient expression levels were considerably lower than the ones observed when using 8 and $11 \mathrm{~cm}$ (Table 1); this may be due to the velocity decrease of the microcarriers that reduces the penetration force and DNA integration (Suratman et al. 2010).

The osmotic treatment prior to particle bombardment is used to reduce cell damage, enhance transient GUS expression, increase stable transformation, and facilitate cell membrane stabilization after transformation (Suratman et al. 2010). The previous studies made in nopal utilized a 12-16-h period of exposition prior to particle bombardment, but the osmotic agent was not described (Llamoca-Zarate et al. 1999b). This differs consistently with our findings (Table 1), since, when the exposition time was increased, we found a statistically significant decrease $(\alpha=0.05)$ in foci production.

Transgene copy number is influenced by the amount of DNA used for every bombardment, and thus, singlecopy integration is favored when lower amounts of DNA are loaded into microcarriers (Lowe et al. 2009). This is in agreement with our results. The highest GUS transient expression was observed when using $1.0 \mu \mathrm{g} / \mu \mathrm{L}$ (Table 1; Fig. 2c). This was also observed in plant species like tomato (Camacho-Beltrán 2008). Unfortunately, the previous reports in nopal particle bombardment do not describe which plasmid DNA concentration was used (Llamoca-Zarate et al. 1998, 1999b). On the other hand, limiting the DNA amount used for particle bombardment results in fewer DNA molecules covering an individual particle (Lowe et al. 2009). This coincides with our results, where the use of $0.5 \mu \mathrm{g} / \mu \mathrm{L}$ resulted in less foci production when compared with the use of $1.0 \mu \mathrm{g} / \mu \mathrm{L}$. Interestingly, when a DNA concentration of $1.5 \mu \mathrm{g} / \mu \mathrm{L}$ was used, we did not observe a higher level of foci production (Table 1). 
Gold and tungsten particles differ in their ability to generate foci and stable transformation events due to their overall shape, penetration depth, toxicity, and foci formation size (Altpeter et al. 2005; Rivera et al. 2012). In the present study, gold particles gave a higher number of blue spots per explants (Table 1; Fig. 2d). The low levels of transient GUS expression in the tungsten bombarded explants could be due to a toxic effect (Rivera et al. 2012). Since nopal tissue architecture is more complex, this could prevent the penetration of tungsten particles into deeper cell layers, thereby generating a lower transient GUS expression level. Nevertheless, in the previous reports, tungsten particles of $1.3 \mu \mathrm{m}$ diameter were used during the particle bombardment of nopal apical meristems, generating acceptable results in terms of transient GUS expression (Llamoca-Zarate et al. 1999b). Similar results to the ones reported here were registered in Jatropha curcas, where the use of $900 \mathrm{psi}$ and $0.6 \mu \mathrm{m}$ gold particles generated a higher survival percentage in bombarded tissues (Joshi et al. 2011).

The type and concentration of the osmotic agent may increase the transient gene expression by reducing the turgor pressure in cells, helping to increase the survival probability of the cells by avoiding cell rupture after the blast generated from the bombardment (Rosillo et al. 2003). The positive effect of using mannitol and combinations with sorbitol has already been reported in plant systems such as watermelon (Suratman et al. 2010) and coffee (Gatica et al. 2009). Even though the use of mannitol generated positive results in foci formation (Table 1), the sorbitol + mannitol treatment and the maltose + sorbitol + mannitol treatment did not generate any synergic effect that could enhance GUS expression. However, the results presented here are far higher than the ones reported by Llamoca-Zarate et al. (1999b). In other words, we report 197 positive GUS events (only for the mannitol $0.2 \mathrm{M}$ treatment) versus 35 reported by that research group. In brief, the results presented here may be regarded as robust and allowed the establishment of nopal particle bombardment conditions by means of transient expression; such conditions are: a distance of flight to the target tissue of $8 \mathrm{~cm}$; a helium pressure of $900 \mathrm{psi}$, a pre-conditioning period for the nopal explants of $4 \mathrm{~h}$ prior to the bombardment using $0.2 \mathrm{M}$ mannitol as the osmotic agent, and the utilization of gold particles as microcarriers on which $1 \mu \mathrm{g} / \mu \mathrm{L}$ of plasmid DNA is previously loaded.

\section{Stable nopal genetic transformation by particle bombardment}

Particle bombardment constitutes an alternative method for gene transfer in those cases where the other methods are not efficient, since it may facilitate DNA delivery into intact plant cells with no biological constraints or host limitations (Tassy et al. 2014; Wang et al. 2018). With our transformation protocol, we obtained a $23 \%$ of transformation efficiency and survival on selection medium which is higher than the ones reported for the other plant species such as marigold that was 1\% (Vanegas-Espinoza et al. 2006), 8\% for A. tequilana (Valenzuela-Sánchez 2006), and $1.8 \%$ for tomato (Camacho-Beltrán 2008). In addition, when we compared the results obtained with plant models more closely related to nopal, we found that the overall biolistic transformation efficiency in nopal was higher than the one previously registered for Aloe vera (8.7\%) (Velchevá et al. 2010). Interestingly, our results are close to the ones reported for Rhipsalidopsis gaertner (22.7\%) after A. tumefaciens genetic transformation (Al-Ramamneh et al. 2006).

In addition, Llamoca-Zarate et al. (1998, 1999b) reported transient GUS expression in nopal explants after particle bombardment; nevertheless, they never achieved stable genetic transformation or regeneration of the transformed explants. In addition, Cruz et al. (2009) reported 4\% transformation efficiency by biolistics in nopal apical tissues. However, no stable integration of the transgene was demonstrated. Furthermore, Silos-Espino et al. (2006) achieved a $3.2 \%$ rate of genetic transformation efficiency in $O$. ficusindica $\mathrm{cv}$. Villanueva transformed by means of A. tumefaciens. However, the results presented here by the biolistics process are consistently higher. This could be due to the fact that the nopal transformation by the A. tumefaciens method presents some serious difficulties. Experiments to establish O. ficus-indica cv. Blanco sin Espinas genetic transformation by means of $A$. tumefaciens infection were conducted, with no positive results (data not shown). In fact, Karami et al. (2009) described that, when using the A. tumefaciens, gene transfer can be very different within the same plant species, even at the cultivar level. Therefore, the particle bombardment method established in nopal presents advantages, since one should not have to overcome plant-related issues such as those involved in the A. tumefaciens method.

\section{Transgene integration assessment in nopal stable transformants}

Stable integration of the transgene into the plant genome by different genetic transformation protocols remains a very difficult task. One of the main disadvantages associated with the biolistics gene transfer method is related to the cosuppression phenomenon or transgene rearrangements that can prevent transgene integration, limit its proper expression, or inhibit the production of the foreign protein (Lowe et al. 2009). Thus, obtaining positive results in terms of transgene expression in nopal explants may be considered a very important step. With the method described previously, we were capable of detecting the integration of both nptII and uidA transgenes by means of PCR, in all the transformed samples (Fig. 3a, b). Other reports made in nopal 
with biolistics were able to detect only the transient GUS expression without demonstrating the stable integration of the transgene into the plant genome (Llamoca-Zarate et al. 1998, 1999b). However, the sole report that had previously demonstrated the capacity of nopal for the introduction of transgenes was published by Silos-Espino et al. (2006). In this case, the stable integration of the nptII gene was demonstrated by PCR and Southern blot hybridization. On the other hand, our method allowed the expression of these transgene transcripts as revealed by the RT-PCR analysis of transformed materials (Fig. 4c, d), therefore demonstrating the capacity of this plant to express heterologous transgenes. However, this happened in a slightly unexpected way, as 10 out of 10 samples revealed the expression of the $n t p I I$ transgene, while only 8 out of 10 revealed the expression of the uidA gene. No information is yet available for the nopal gene silencing machinery; however, we can deduct from the results obtained, that this behavior may be due to a cosuppression event that caused the "turning off" of the uidA transgene in this plant or maybe to transgene rearrangements during RNA transcription (Lowe et al. 2009).

Stable expression and production of proteins in nopal was analyzed by a GUS fluorescent assay. The values obtained in this report were in average $304 \mathrm{MU} / \mathrm{min} / \mathrm{mg}$ protein which were consistently lower than the ones detected in the control sample (commercial $\beta$-glucuronidase). Thus, this constitutes apparently the first report indicating the feasibility of using a very complicated plant for the introduction of foreign DNA into the plant genome and, in the last instance, the production of heterologous proteins.

\section{Conclusions}

An efficient particle bombardment protocol for nopal $(O$. ficus-indica) cv. "Blanco sin Espinas" was developed; adjusting parameters for particle bombardment led to enhanced transformation efficiency as we have described in this study. Moreover, we were capable of detecting the nptII and uidA transgenes after the RT-PCR process, which demonstrates the capacity of nopal explants for the expression of heterologous genes. Finally, we were also capable of detecting adequate $\beta$-glucuronidase protein level, demonstrating that this ancient plant may be used for the production of heterologous proteins. Further studies are needed to improve the production of proteins in this plant, to use it as a bioreactor plant system.

Acknowledgements The authors would like to thank Consejo Nacional de Ciencia y Tecnología (CONACyT), Consejo Estatal de Ciencia y Tecnología del Estado de Sinaloa (CECyT), and Universidad Autónoma de Sinaloa for the scholarships to P.I.A.B. CONACyT is also acknowledged for the partial support for this project. We kindly thank PRONOPVAL, Valtierrilla, Guanajuato, for providing the nopal samples used in this study. We also acknowledge the technical support of Dr. José Luis Hernández-Flores, Dr. Hamlet Avilés-Arnaut, and Dr. Héctor Gordon Nuñez-Palenius.

Author contributions Angulo-Bejarano Paola I, Sharma Ashutosh, and Paredes López Octavio all contributed equally in this research.

\section{Compliance with ethical standards}

Conflict of interest On behalf of all authors, the corresponding author states that there is no conflict of interest.

Open Access This article is distributed under the terms of the Creative Commons Attribution 4.0 International License (http://creativeco mmons.org/licenses/by/4.0/), which permits unrestricted use, distribution, and reproduction in any medium, provided you give appropriate credit to the original author(s) and the source, provide a link to the Creative Commons license, and indicate if changes were made.

\section{References}

Al-Ramamneh EA, Sriskandarajah S, Serek M (2006) Agrobacterium tumefaciens-mediated transformation of Rhipsalidopsis gaertneri. Plant Cell Rep 25:1219-1225. https://doi.org/10.1007/s0029 9-006-0190-x

Altpeter F, Baisakh N, Beachy R, Bock R, Capell T, Christou P, Daniell H, Datta K, Datta S, Dix PJ, Fauquet C, Huang N, Kohli A, Mooibroek H, Nicholson L, Thanh TN, Nugent G, Raemakers K, Romano A, Somers DA, Stoger E, Taylor N, Visser R, Fauquet C (2005) Particle bombardment and the genetic enhancement of crops: myths and realities. Molec Breed 15(3):305-327. https:// doi.org/10.1007/s11032-004-8001-y

Angulo-Bejarano PI (2013) Desarrollo de estrategias para la utilización del nopal (Opuntia ficus-indica) como biorreactor vegetal (Development of strategies for the utilization of nopal as plant bioreactor). Centro de Investigación y de Estudios Avanzados del Instituto Politécnico Nacional, Unidad Irapuato. PhD thesis. Irapuato, Gto, México

Angulo-Bejarano PI, Paredes-López O (2012) Nopal: a perspective view on its nutraceutical potential.In: Tunick $\mathrm{M}$ et al. (Eds) Hispanic foods: chemistry and bioactive compounds, vol 1109. American Chemical Society, pp 113-159. https://doi.org/10.1021/ bk-2012-1109.ch009

Angulo-Bejarano PI, Paredes-López O (2011) Development of a regeneration protocol through indirect organogenesis in prickly pear cactus (Opuntia ficus-indica (L.) Mill). Sci Hortic 128:283-288. https://doi.org/10.1016/j.scienta.2011.01.030

Angulo-Bejarano PI, Martínez-Cruz O, Paredes-López O (2014) Phytochemical content, nutraceutical potential and biotechnological applications of an ancient Mexican plant: nopal (Opuntia ficusindica). Curr Nutr Food Sci 10:196-217

Blanco F, Valdez RD, Ruiz RR, Márquez MM (2003) Congreso, Memorias del IX Congreso Nacional. Producción intensiva de nopalito en camas de Zacatecas, Internacional sobre Conocimiento y Aprovechamiento del Nopal Septiembre 2-6. Zacatecas, México, pp 168-172

Britton NL, Rose JN (1963) The Cactaceae; descriptions and illustrations of plants of the cactus family (vol. 3) Courier corporation. Dover publications. Nueva York, EU

Camacho-Beltrán E (2008) Manipulación de los contenidos de carotenoides mediante la expresión del gen $\beta$-licopeno ciclasa $(l c y-b)$ en

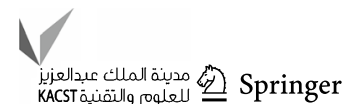


cloroplastos de plantas de tabaco y tomate. MSc thesis. Programa de Posgrado en Alimentos del Centro de la República (PROPAC) Universidad Autónoma de Querétaro, Santiago de Querétaro, Qro

Chernobrovkina MA, Sidorov EA, Baranov IA, Kharchenko PN, Dolgov SV (2007) The effect of the parameters of biolistic transformation of spring barley (Hordeum vulgare L.) on the level of transient expression of GFP reporter gene. Biology Bulletin 34:558 - 63. https://doi.org/10.1134/S1062359007060040

Cruz ARR, Soares EL, Campos FAP, Aragão FJL (2009) Biolisticmediated genetic transformation of prickly-pear cactus (Opuntia ficus-indica Mill.). Acta Hortic 811:255-257

Daniell H, Dhingra A, Kumar S (2004) Stable transformation of the cotton plastid genome and maternal inheritence of transgenes. Plant Mol Biol 56:203-216. https://doi.org/10.1007/s1110 3-004-2907-y

Datla RSS, Hammerlindl JK, Pelcher LE, Crosby WL, Selvaraj G (1991) A bifunctional fusion between $\beta$-glucuronidase and neomycin phosphotransferase: a broad-spectrum marker enzyme for plants. Gene 101:239-246. https://doi.org/10.1016/03781119(91)90417-A

García-Saucedo PA, Valdéz-Morales M, Valverde ME, Cruz-Hernández A, Paredes-López O (2005) Plant regeneration of three Opuntia genotypes used as human food. Plant Cell Tiss Organ Cult 80:215-219. https://doi.org/10.1007/s11240-004-9158-0

Gatica AM, Arrieta G, Espinoza AM (2009) Optimization of coffee (Coffea arabica) transformation parameters using uidA and $h p t$ genes: effect of osmotic pre-treatment, helium pressure and target distance. Revista de Biología Tropical 57:151-160

Gibson AC, Nobel PS (1986) The cactus primer. Harvard University Press, Cambridge

Hagio T, Hirabayashi T, Machii H, Tomotsune H (1995) Production of fertile transgenic barley (Hordeum vulgare L.) plant using the hygromycin resistance marker. Plant Cell Rep 14:329-334. https ://doi.org/10.1007/BF00232038

Herrera A (2009) Crassulacean acid metabolism and fitness under water deficit stress: if not for carbon gain, what is facultative CAM good for? Annals Bot 103:645-653. https://doi.org/10.1093/aob/ men 145

Jefferson RA (1987) Assaying chimeric genes in plants: the GUS gene fusion system. Plant Mol Biol Rep 5:387-405. https://doi. org/10.1007/BF02667740

Joshi M, Mishra A, Jha B (2011) Efficient genetic transformation of Jatropha curcas L. by microprojectile bombardment using embryo axes. Ind Crops Prod 33:67-77. https://doi.org/10.1016/j. indcrop.2010.09.002

Karami O, Esna-Ashari M, Karimi Kurdistani G, Aghavasi B (2009) Agrobacterium-mediated genetic transformation of plants: the role of host. Biol Plantarum 53:201-212. https://doi.org/10.1007/ s10535-009-0041-z

Llamoca-Zárate RM, Landsmann J, Campos FAP (1998) Establishment and transformation of callus and cell suspension cultures of the prickly-pear (Opuntia ficus-indica). JPACD 4:27-36

Llamoca-Zárate RM, Studart-Guimarães C, Landsmann J, Campos FAP (1999a) Establishment of callus and cell suspension cultures of Opuntia ficus-indica. Plant Cell Tiss Organ Cult 58:155-157. https://doi.org/10.1023/A:1006315729266

Llamoca-Zárate RM, Landsmann J, Campos FAP (1999b) Biolisticmediated transient gene expression in shoot apical meristems of the prickly-pear (Opuntia ficus-indica). Braz Arch Biol Technol 42:299-302

Lowe B, Shiva Prakash N, Way M, Mann MT, Spencer TM, Boddypalli RS (2009) Enhanced single copy integration events in corn via particle bombardment using low quantities of DNA. Trans Res 18:831-840. https://doi.org/10.1007/s11248-009-9265-0

Murashige T, Skoog F (1962) A revised medium for rapid growth and bioassay with tobacco tissue culture. Plant Physiol 15:473-479

Petrillo CP, Carneiro NP, Purcino AAC, Carvalho CHS, Alves JD, Carneiro AA (2008) Optimization of particle bombardment parameters for the genetic transformation of Brazilian maize inbred lines. Pesquisa Agropecuária Brasilia 43:371-378

Rivera AL, Gómez-Lim M, Fernández F, Loske AM (2012) Physical methods for genetic plant transformation. Phys Life Revs 9:3:308 345. https://doi.org/10.1016/j.plrev.2012.06.002

Rosillo G, Acuña J, Gaitan A, De Peña M (2003) Optimized DNA delivery into Coffea arabica suspension culture cells by particle bombardment. Plant Cell Tiss Organ Cult 74:45-49. https://doi. org/10.1023/A:1023314128543

Rubio S, Jouve N, González JM (2004) Biolistic transfer of the gene uidA and its expression in haploid embryo-like structures of triticale (Triticosecale Wittmack). Plant Cell Tiss Organ Cult 77:203209. https://doi.org/10.1023/B:TICU.0000016827.02241.1f

Silos-Espino H, Valdez-Ortiz A, Rascón-Cruz Q, Rodríguez-Salazar E, Paredes-López O (2006) Genetic transformation of pricklypear cactus (Opuntia ficus-indica) by Agrobacterium tumefaciens. Plant Cell Tiss Organ Cult 86:397-403. https://doi.org/10.1007/ s11240-006-9123-1

Suratman F, Huyop F, Wagiran A, Rahmat Z, Ghazali H, Parveez GKA (2010) Biolistic transformation of Citrullus vulgaris Schrad (Watermelon). Biotechnology 9:119-130

Tassy C, Partier A, Beckert M, Feuillet C, Barret P (2014) Biolistic transformation of wheat: increased production of plants with simple insertions and heritable transgene expression. Plant Cell Tiss Cult 119:171. https://doi.org/10.1007/s11240-014-0524-2

Valderrama-Chairez ML, Cruz-Hernández A, Paredes-López O (2002) Isolation of functional RNA from cactus fruit. Plant Mol Biol Rep 20:279-286. https://doi.org/10.1007/BF02782463

Valenzuela-Sánchez KK, Juárez-Hernández RE, Cruz-Hernández A, Olalde-Portugal V, Valverde ME, Paredes-López O (2006) Plant regeneration of Agave tequilana by indirect organogenesis. In Vitro Cell Develop Biol Plant 42:336-340. https://doi. org/10.1079/IVP2006788

Vanegas-Espinoza PE, Valdez-Morales M, Valverde ME, Cruz-Hernández A, Paredes-López O (2006) Particle bombardment, a method for gene transfer in marigold. Plant Cell Tiss Organ Cult 84:359363. https://doi.org/10.1007/s11240-005-9030-x

Velchevá M, Faltin Z, Vardi A, Hanania U, Eshdat Y, Dgani O, Sahar N, Perl A (2010) Aloe vera transformation: the role of Amberlite XAD-4 resin and antioxidants during selection and regeneration. In Vitro Cell Dev Biol Plant 46:477-484. https://doi.org/10.1007/ s11627-010-9301-z

Wang H, Zhao Q, Fu J, Wang X, Jiang L (2018) Re-assessment of biolistic transient expression: An efficient and robust method for protein localization studies in seedling-lethal mutant and juvenile plants. Plant Sci 274:2-7. https://doi.org/10.1016/j.plant sci. 2018.03 .032 